ELK ASIA PACIFIC JOURNAL OF SOCIAL SCIENCE

ISSN 2394-9392 (Online); DOI: 10.16962/EAPJSS/isSn. 2394-9392/2015; Volume 5 Issue 1 (2018)

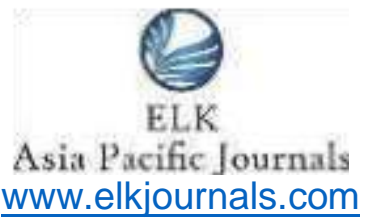

\title{
SUCCESS OR FAILURE OF INDIAN CPSES: AN ANALYTICAL APPROACH
}

\begin{tabular}{|c|c|}
\hline $\begin{array}{c}\text { M.D. Sreekumar } \\
\text { K.R Mangalam University, Gurgaon } \\
\text { mdsreekumarhmt@gmail.com }\end{array}$ & $\begin{array}{c}\text { Dr. Meghna Chabbra } \\
\text { K.R Mangalam University, Gurgaon } \\
\text { Meghnachhabra28@gmail.com }\end{array}$ \\
\hline
\end{tabular}

\begin{abstract}
The Enterprises under public sector were set up to assist the comprehensive macroeconomic intentions, i.e. higher economic growth, self-sufficiency in production of goods and services, longterm equilibrium in the balance of payments and finally low and stable prices apart from certainsocio-economic obligations. Further, the study discloses that most of the CPSEs are underperforming due to countless constraints like lack of autonomy, poor infrastructure, excessive NonPerforming Assets (NPAs), corruption and political interference. However, there are some CPSEs which experienced success because of the public-private partnership (PPP), community outreach, risk awareness, and effective communication. However, to study the success or failure of Indian Central Public Sector Enterprises (CPSEs), this research is conducted in an analytical approach. The study mainly focuses on the evolutions of Public Sector Enterprises (PSEs), CPSEs contribution; factors influencing the performance and the rationale of PSEs in India. The results discovered that even though the CPSEs are technically strong, they couldn't perform better due to poor infrastructure, Non-Performing Assets (NPAs), corruption, etc., followed by success factors like Public-Private Partnership (PPP), risk awareness, etc. Ultimately, the researcher has proposed recommendations that ensure productivity and sustainable growth of the sector.

Keywords: Public Sector Enterprises, success or failure of Indian CPSEs, evolution, performance, rationale of PSEs, performing assests, corruption, productivity etc.
\end{abstract}

\section{INTRODUCTION}

Public sector enterprises were set up to serve the broad macroeconomic objectives, i.e., higher economic growth, self-sufficiency in production of goods and services, long-term equilibrium in the balance of payments and finally low and stable prices apart from certain socio-economic obligations. However, to study the success or failure of Indian Central Public Sector Enterprises (CPSEs), this research is proposed to be conducted through an analytical approach. The study mainly focuses on the evolutions 


\section{ELK ASIA PACIFIC JOURNAL OF SOCIAL SCIENCE}

ISSN 2394-9392 (Online); DOI: 10.16962/EAPJSS/issn. 2394-9392/2015; Volume 5 Issue 1 (2018)

of Central Public Sector Enterprises (CPSEs), their rationale and contribution in the economic growth of India and factors influencing their performance. The results revealed that even through the CPSEs are technically strong, they couldn't perform better due to so many reasons. Similarly, so many factors could be identified behind excellent performance of few other CPSEs. Ultimately, the researcher plans to formulate recommendations that ensure productivity and sustainable growth of the sector.

The Government of India set out in their Resolution dated 6th April, 1948, emphasized the importance to the economy of securing a consistent increase in production and its equitable distribution, also stressed out that the State must actively participate in the development of industries (p1. Industrial Policy Resolution, 1956). The main purpose for setting up of PSUs was to strengthen and accelerate the core sectors of the economy, to serve the equipment needs of strategically important sector, and finally to generate employment and income. Based on the Performance Report (2015) published by Department of Public Enterprises in India, "all public sector undertakings collectively accounted for 23.2 percent of the total market capitalization" and "these organizations contribute totally 9 percent of India's total export earnings".

The banking sector in India also witnessed and experienced the concept of public sector undertaking. Nationalization of the Imperial Bank of India made the path to the public sector into commercial banking. This is one of the initiatives carried by the government in the process of public ownership and control of the national economy and its strategic sectors, in concurrence with the Parliament's mandate that is for the progress of a socialist pattern of society. In addition, the State Bank of India required to stretch its wings to the rural areas by introducing new services to the rural community and give them adequate credit facilities. Apart from that, the State Bank of India was also expected to assist the Reserve Bank of India to flow of credit in accordance with the national priorities which established in the Five-Year plans. (Rangaswamy, 2016)

Similarly, in the agricultural sector, there was a major change in public sector extension after the implementation of the World Bank sponsored Training and Visit System (T \& V) in 1974. This significant step eventually improved the financial and human resource capacity in the country. However, due to less manpower in some of the states, 
the Kishan Vikas Kendra (KVKs) reach limited to a smaller number of farmers. Plus, many KVKs constrained because of financial, infrastructural, and human resource limitations and unable to reach the farming community of an area. (Sajesh \& Suresh, 2016)

\section{EVOLUTION OF PUBLIC SECTOR ENTERPRISES (PSEs) IN INDIA}

Public Sector Enterprises (PSEs) in India started to fulfill the responsibility of specific social goals such as correcting the local, regional and national economic imbalances, generating employment and mitigation of concentration of monopoly power in the economy. Mishra and Potaraju (2016) studied the system of performance management in Central Public Sector Enterprises, where they stated that the Public Sector in India has basic philosophy and ethos of Public Sector highlighted the necessity for obtaining a comprehensive network of infrastructure facilities to promote rapid industrialization and economic growth.

At the time of independence, public sector investment was restricted to railways, the post and telegraphs department, the ordnance factories, followed by a few states managed factories like the quinine factories, salt factories, etc. Several initiatives were taken to bring a culture of professionalism and competition among them counterparts; one such initiative is to introduce the Memorandum of Understanding (MoU) system (Mishra \& Potaraju, 2016). Over the period, the Department of Public Enterprises had made submissions of Self Evaluation Reports, to enhance corporate governance, mandatory for central government-owned enterprises. This exercise was carried out by only $40 \%$ of the enterprises in India (Jain \& Kumar, 2016). Further, the governmentowned Indian service companies (including manufacturing, pharma, and chemical) face failures in their targets, due to intangibility, inseparability, variability, and perishability. If the same situation persists, the service organizations should control and mitigate the failure from happening. Such an approach is the legacy of monopoly environment in which these were operating in not so long back (Bhardwaj \& Rani, 2014).

\section{RATIONALE OF PSEs IN INDIA}

The rationale behind PSUs is to accelerate rapid economic development, reduce concentration of economic powers, balance regional development, and generate employment opportunities, import substitution, export promotion, and resource mobilization. Government orders for PSUs 


\section{ELK ASIA PACIFIC JOURNAL OF SOCIAL SCIENCE}

ISSN 2394-9392 (Online); DOI: 10.16962/EAPJSS/issn. 2394-9392/2015; Volume 5 Issue 1 (2018)

generally aim at betterment of the society (Peng, Bruton, Stan, and Huang, 2016). Arms and ammunition, defense equipment, defense aircrafts, warships, atomic energy, railways transport, heavy metals, aircraft, ships, petroleum, coal, natural gas, and power generation come under PSUs in India (Kumar \& Saha, 2017).

PSEs are the building blocks of the Indian economy and have a unique position in the country's socio-economic development. Since these organizations are government-owned, they have additional commitments for the economic, social and environmental well-being of the people. (Mansi, Pandey, \& Ghauri, 2017) At the local level, the urban public sector service provision is still insufficient to satisfy the basic needs of slum residents across India (Pierce, 2016). The central public sector enterprises (CPSEs) form an integral part of the Indian economy. These enterprises played a prominent role in the country's economic growth and development. To stay competitive in the open economy and to meet the private sector's efficiency Department of Public Enterprises (DPE) took up the measure of empowering the profit-making CPSEs by granting them operational and financial autonomy. (Pandey \& Dutta, 2015).
Mansi, Pandey, and Ghauri (2017) stated that the Indian public sector enterprises (PSEs), are unique in some ways. Firstly, these enterprises are government owned with a monopoly in nuclear power generation along with a major market share in the coal, petroleum, power generation, telecommunication, and fertilizers sectors. Secondly, several enterprises have listed in the Bombay Stock Exchange (BSE) and few of them are also part of S \& P BSE 100 index (ITC, BPCL, ONGC, GAIL, SAIL, and NTPC). In the banking sector, the Government of India promulgated an ordinance "Banking Companies (Acquisition and Transfer of Undertakings) Ordinance, 1969" through which the government incorporated 14 biggest commercial banks. To justify nationalization, the former Prime Minister, Late Smt., Indira Gandhi had said that "An institution such as the banking system, which touches and should touch the lives of millions, has necessarily to be inspired by a larger social purpose and has to sub serve national priorities and objectives. That is why there has been a widespread demand that the major banks should be not only socially controlled but publicly owned. The step we have now taken is a continuation of the process which has long been underway." (Rangaswamy, 2016). 


\section{ELK ASIA PACIFIC JOURNAL OF SOCIAL SCIENCE}

ISSN 2394-9392 (Online); DOI: 10.16962/EAPJSS/issn. 2394-9392/2015; Volume 5 IsSue 1 (2018)

CPSEs CONTRIBUTION TO INDIAN ECONOMY

Mandiratta and Bhalla (2017) have evaluated the performance of Indian CPSEs of Pre and Post Disinvestment. The research endeavored to scientifically examine the financial and operating performance of 15 Central Public Sector Enterprises (CPSEs) via public share offering mode during the period 2003 - 2012. The four major groups that measured are manufacturing, mining, electricity, and service sectors. The study results reveal that there is a significant increase in sales efficiency and net income efficiency, which covers the overall operating efficiency, but in the case of profitability position, there is an insignificant result. Likewise, state-owned enterprises (SOEs) in India played a crucial role in the country's development. After the introduction of MoU system in the stateowned enterprises has gone beyond the original objective of grant of greater autonomy. (Kumar, 2018) The SOEs helped the government to control specific strategic sectors of the economy. Also, it helps the consumers from exploitation by private enterprises by offering them cheaper and better service.
Subramanian, Kansal, and Babu (2017) studied the Corporate Social Responsibility owned by government firms. They provided evidence on the governance of CSR policies and activities by Indian central government-owned companies [i.e., Central Public Sector Enterprises (CPSEs)] under a mandatory regulatory setting. The study has found that the CSR policy implementation within Indian CPSEs is nascent, fraught with bureaucratic human and knowledge gap, limited stakeholder analysis and finally overemphasis on CSR budget. Thus, there is an urging need for clearer communication with external service providers, building strategies, and policy development. Corporate social responsibility (CSR) is an emerging responsibility to the corporate companies where they voluntarily contribute to building a better society with a cleaner environment. Paramasivan and Savarimuthu (2015) have studied the CSR of Ratna status public sector undertakings in India and aimed to highlight the significance of it. As per the study, the researchers proposed that India needs more contribution to strengthen the socio-economic infrastructural development even though there are numerous supporting agencies like government corporate and nongovernmental sectors available. The study concluded that more policy formulation and 


\section{ELK ASIA PACIFIC JOURNAL OF SOCIAL SCIENCE}

ISSN 2394-9392 (Online); DOI: 10.16962/EAPJSS/issn. 2394-9392/2015; Volume 5 Issue 1 (2018)

sanction is not enough to fulfill the intention of CSR. Instead, there is a need for monitor mechanism with the association of local government and reputed NGOs.

Shah (2018) studied the initiatives of public sector investments for infrastructure development for the horticulture sector in India. The results show that despite the efforts and initiatives were undertaken by the NHB, NCDC, APEDA, NABARD, Commercial Banks, and other funding agencies to produce proper and effective post-harvest infrastructure for horticulture crops, the PHI developments concerning facilities are not impressive till the present. The policies started in the early 2000 and various programme initiatives were undertaken in the recent past by the NHB, NCDC, APEDA, NABARD, Food Processing Industry that are engaged to develop PHI facilities, plus the private sector investment in horticulture have measurably a fresh fillip not only to the expansion of the horticulture production, but also the exports of these high value products from the country.

\section{FACTORS INFLUENCING THE PERFORMANCE OF INDIAN CPSES:}

Khanna (2015) in his research examined the increasing profitability and investment in larger CPSEs due to being efficient competitors in the new market environment at the same time with a diminishing institutional role. It emphasized that most of the CPSEs are technically outstanding which made them better-run and professionally managed entities. In a comparison between the private and public sector firms with a turnover of more than Rs. 10,000 crore in 2009 results that the CPSEs in manufacturing provided more substantial returns on capital employed when compared to the private counterparts. Due to technical strength possessed by the CPSEs made it outperform the private firms like plant load factor in electricity generation, similarly yields from the steel and petroleum industry.

Khanna and Gupta (2015) have studied the customer's perception on Banks Technology for Innovative Delivery Channels of Public Sector Banks (PSBs) of India, in which the study was based on primary data by conducting a survey as well as a personal interview of customers and managers. The study primarily focused on five factors viz., acceptability, safety, availability, user-friendliness, and accessibility. The study results reveal that the above factors highly depend on the demographic profile of the population size. 


\section{ELK ASIA PACIFIC JOURNAL OF SOCIAL SCIENCE}

ISSN 2394-9392 (Online); DOI: 10.16962/EAPJSS/issn. 2394-9392/2015; Volume 5 Issue 1 (2018)

And most of the marketing decisions aimed to enhance the effectiveness of delivery channels can be taken by considering these factors. For customers who have never used technology, the public sector banks should channelize by providing value-added services.

Mansi (2015) aimed to explore the sustainable procurement disclosure and reporting practices in the Central Public Sector Enterprises (CPSEs) in India and to understand how CPSEs operationalize and disclose sustainable procurement (SP) practices. Additionally, this research developed a reliable and robust sustainable procurement disclosure index (SPDI). From the eight different SP dimensions examined, the maximum disclosures come under economic development, philanthropy, and community development practices. However, the researcher failed to mention the reasons for the rest of the dimensions, why it didn't perform or contribute well to the country, followed by the targeted sample in which banks got excluded. Since public sector banks play a major role in economic development and growth, it must have included in the sample size.

Banerjee, Baul, and Rosenblatt (2015) conducted an experiment on corruption with private sector job aspirants and aspirants of Indian bureaucracy. The researchers utilized the game model embezzlement of resources to evaluate the performance of workers by the supervisors and then pay them their salary. At the end of the study, they found that aspirant bureaucrats indulge in corruption more than the private sector counterparts, but still the likelihood of being corrupt is the same to both the sectors. In this study, the researchers considered only the Union Public Service Examination (UPSC) to analyze the aspirant bureaucrats which is inadequate and couldn't draw conclusions. Since public sector comprises of both state and central level exams, the researcher could have taken one or more state public sector examination. Similarly, for the private sector, the researchers could have chosen some more streams apart from MBA to study and analyze the corrupt behavior.

In this paper, the researcher aimed to study the success or failure of Indian CPSEs through an analytical approach. The paper comprises of topics such as the evolution of public sector enterprises (PSEs) in India, CPSEs contribution to the Indian economy, factors influencing the performance of Indian CPSEs, and rationale of PSEs in India. Even 


\section{ELK ASIA PACIFIC JOURNAL OF SOCIAL SCIENCE}

ISSN 2394-9392 (Online); DOI: 10.16962/EAPJSS/issn. 2394-9392/2015; Volume 5 Issue 1 (2018)

though the topics are relevant to the objectives, it can be more specific like the growth rate of CPSEs, impact in the economy, and development in the society. Apart from that, the data collected is not entirely reliable, because the papers reviewed in this research consists of employees opinion concerning limiting factors in CPSEs and not the major factors influencing the success or failure of the concerned organization.

Based on the references, several factors are highlighted. 1) The Indian CPSEs are technically strong, highly efficient and capable of performing better than now, but due to the current economic policies and market, they incur a huge financial loss. 2) The Indian banking sector is progressing towards technology-driven service which is a welcoming initiative, at the same time the management should have necessary prerequisites for people who never used technology before like a person dedicated to guiding them to avail the service. 3 ) The CSR gains momentum in the contribution of the socio-economic infrastructure development which has to channelize promptly. Thus, it results in enormous social and economic impact in the society.
In the Public Enterprises Survey 2015 - 2016, published by Department of Public Enterprises, it broadly discussed about the performance, investment, pricing policy, international operations, Memorandum of Understanding, Research \& Development, and so on. The survey revealed that the Manufacturing sector contributes majority of the share of $61.52 \%$ of the total turnover achieved by CPSEs during 2015 - 2016, followed by Services sector (20.20\%), Mining sector (11.47\%), Electricity sector $(6.76 \%)$ and Agriculture sector (0.05\%). The total employee strength in CPSEs stood at 12.34 lakh (excluding contractual workers) in 2015 - 2016, compared to 12.91 lakh in 2014 - 2015. Due to superannuation, voluntary retirement, etc., the total strength of employees in CPSEs came down by 57,560 persons (p11, Public Enterprises Survey, 2015 - 2016). Some researches provide that the corrupt practices prevail more in the government-owned enterprises than the private counterparts. The corruption is a severe impediment to the CPSEs and the government at large, as it stagnates growth and development in the country. However, if the CPSEs and the government (including legislation) come together and build successful strategies, they might overcome 


\section{ELK ASIA PACIFIC JOURNAL OF SOCIAL SCIENCE}

ISSN 2394-9392 (Online); DOI: 10.16962/EAPJSS/issn. 2394-9392/2015; Volume 5 Issue 1 (2018)

the present chaos and ensure a better society for the people.

The study reveals that most of the CPSEs are under-performing due to various constraints like lack of autonomy, poor infrastructure, excessive Non-Performing Assets (NPAs), corruption and political interference. However, there are some CPSEs which experienced success because of the public-private partnership (PPP), community outreach, risk awareness, and effective communication. Moreover, the CPSEs try to achieve higher productivity, efficiency and ultimately contribute to the GDP growth. The Hon'ble Prime Minister said that "out of the 500 biggest companies in the world, onefourth belong to the public sector in some country. CPSEs have modern R\&D infrastructure, in addition to the facilities that exist in CSIR and ICAR, etc.” (PIB, PM addresses CPSE Conclave, 2018). Additionally, he said that innovation and research now need to be integrated and called for more excellent information sharing among CPSEs and Government Departments. No material could be found which gives a holistic approach of factors behind the success or failure of Indian CPSEs. Similarly, no attempt is seen made on prioritization of different factors behind their success or failure. It can be therefore concluded that ample scope exists for further research study on above. Recommendations which can be formulated at the end of the proposed research study may motivate, inspire and guide the decision makers and other stakeholders of CPSEs to seek insights on the best practices being followed in other PSEs for achieving the desired objectives and set goals in their own enterprises.

\section{REFERENCES}

Banerjee, R., Baul, T., \& Rosenblatt, T. (2015). On self-selection of the corrupt into the public sector. Economics Letters, 127, 43-46.

Bhardwaj, S. S., \& Rani, M. (2014). An inter-industry comparison of service recovery in selected public sector service organizations of India. Journal of Marketing Vistas, 4(1), 34.

Jain, R., \& Kumar, R. (2016). Pawn or Potentates: Corporate Governance Structure in Indian Central Public Sector Enterprises.

Khanna, S. (2015). The transformation of India's public sector. Economic \& Political Weekly, 50(5), 47.

Khanna, V. T., \& Gupta, N. (2015). Customer's perception about banks technology for innovative delivery channels 


\section{ELK ASIA PACIFIC JOURNAL OF SOCIAL SCIENCE}

ISSN 2394-9392 (Online); DOI: 10.16962/EAPJSS/issn. 2394-9392/2015; Volume 5 Issue 1 (2018)

of public sector banks (PSBs) of India. International Journal of Business and Management, 10(2), 214.

Kumar, S. (2018). MoU System in Stateowned Enterprises in India: A Tool in Strategic Management. Indian Journal of Public Administration, 64(1), 36-48.

Kumar, S. P., \& Saha, S. (2017). Influence of Trust and Participation in Decision Making on Employee Attitudes in Indian Public Sector Undertakings. SAGE Open, 7(3), 2158244017733030.

Mandiratta, P., \& Bhalla, G. S. (2017). Pre and Post Disinvestment Performance Evaluation of Indian CPSEs. Management and Labor Studies, 42(2), 120-134.

Mansi, M. (2015). Sustainable procurement disclosure practices in central public sector enterprises: evidence from India. Journal of Purchasing and Supply Management, 21(2), 125-137.

Mansi, M., Pandey, R., \& Ghauri, E. (2017). CSR focus in the mission and vision statements of public sector enterprises: evidence from India. Managerial Auditing Journal, 32(4/5), 356-377.

Mishra, R. K., \& Potaraju, G. (2016). The System of Performance Management in Central Public Sector Enterprises through
Memorandum of Understanding: A Background. Journal of Institute of Public Enterprise, 6.

Pandey, S. C., \& Dutta, A. (2015). Knowledge infrastructure capabilities and knowledge management: case of an Indian public sector undertaking. International Journal of Knowledge-Based Development, 6(1), 50-64.

Peng, M. W., Bruton, G. D., Stan, C. V., \& Huang, Y. (2016). Theories of the (stateowned) firm. Asia Pacific Journal of Management, 33(2), 293-317.

Pierce, G. (2016). Engaging the Local Public Sector to Meet Slum Residents' Practical and Strategic Service Needs: Evidence from Hyderabad, India. SOLUTIONS, 23.

Rangaswamy, B. (2016). Public sector banking in India. Publications Division Ministry of Information \& Broadcasting.

Sajesh, V. K., \& Suresh, A. (2016). PublicSector Agricultural Extension in India: A Note. Review of Agrarian Studies, 6(1), 11631.

Sangwan, A., Prinja, S., Aggarwal, S., Jagnoor, J., Bahuguna, P., \& Ivers, R. (2017). Cost of trauma care in secondary-and tertiary-care public sector hospitals in North 


\section{ELK ASIA PACIFIC JOURNAL OF SOCIAL SCIENCE}

ISSN 2394-9392 (Online); DOI: 10.16962/EAPJSS/issn. 2394-9392/2015; Volume 5 Issue 1 (2018)

India. Applied health economics and health

policy, 15(5), 681-692.

Shah, D. (2018). Infrastructure Development

for Horticulture Sector in India: Public Sector

Investment Initiatives.

Subramanian, N., Kansal, M., \& Babu, S. (2017). Governance of mandated corporate social responsibility: Evidence from Indian government-owned firms. Journal of Business Ethics, 143(3), 543-563. 